\title{
PENGARUH PEMBERIAN KOMBINASI PUPUK MAJEMUK NPK (25:7:7) DAN NPK KEMASAN (10:55:10) TERHADAP PERTUMBUHAN VEGETATIF TANAMAN KAMBOJA JEPANG (ADENIUM OBESUM)
}

\author{
Susi Sulistiana (susi@mail.ut.ac.id) \\ Jurusan Biologi FMIPA-UT
}

\begin{abstract}
The objectives of this research were (i) to identify the effects of combination of compound fertilizers of NPK (25:7:7) and package NPK (10:55:10) on vegetative growth Adenium obesum in stead of Japanese frangipani plant, and (ii) to obtain the best combination of dose of NPK (25:7:7) and package NPK (10:55:10) in order to improve plant vegetative growth of Adenium obesum. This experiment was conducted in employed completely random design with factorial pattern of $4 \times 4$ and three times repetition. Factor I, the dose of NPK (25:7:7) fertilizer in 4 levels of dose : $0.0 \mathrm{~g} / \mathrm{L} ; 0.5$ $\mathrm{g} / \mathrm{L} ; 1.0 \mathrm{~g} / \mathrm{L}$; and $1.5 \mathrm{~g} / \mathrm{L}$. Meanwhile, Factor II, the dose of package NPK (10:55:10) was applied with 4 levels of dose : $0.0 \mathrm{~g} / \mathrm{L} ; 0.5 \mathrm{~g} / \mathrm{L} ; 1.0 \mathrm{~g} / \mathrm{L}$; and $1.5 \mathrm{~g} / \mathrm{L}$. The data obtained were analyzed using variance analysis (ANOVA) technique to identify the influence of the treatment towards variables measured and mean separation was evaluated using DMRT with $5 \%$ level of difference. The results show that the use of combination of compound fertilizers NPK (25:7:7) and package NPK (10:55:10) improves plant vegetative growth of Adenium obesum. However, the use of combination of NPK $0.0 \mathrm{~g} / \mathrm{L}$ and package NPK $0.5 \mathrm{~g} / \mathrm{L}$ shows unsatisafactory results. The combination of NPK 1.5 $\mathrm{g} / \mathrm{L}$ and package NPK $1.5 \mathrm{~g} / \mathrm{L}$ provides the best result in improving plant vegetative growth of Adenium obesum.
\end{abstract}

Key words : fertilizer of NPK, Japanese frangipani, vegetative growth.

Perkembangan dan pembudidayaan tanaman hias semakin pesat dari tahun ke tahun. Tanaman Adenium obesum yang dikenal dengan sebutan kamboja Jepang merupakan salah satu komoditi hortikultura dari jenis tanaman hias dan sangat potensial untuk dikembangkan di Indonesia. Hal ini karena Adenium memiliki keunikan dan daya tarik sebagai tanaman hias, seperti bentuk bunganya yang indah, warna yang beraneka ragam (merah, putih, merah muda, jingga, ungu, dan kuning), serta memiliki berbagai motif bunga (motif strip, bercak, bergaris, dan berbintik-bintik). Di samping itu tanaman kamboja Jepang mempunyai bonggol yang unik dan cantik dengan bentuk yang meliuk-liuk. Bonggol tersebut berasal dari akar yang tumbuh semakin besar sesuai dengan pertambahan umur (Untung, 2006).

Sebagai salah satu tanaman hias populer dan favorit, tanaman Adenium mempunyai nilai ekonomi yang cukup tinggi untuk dibudidayakan sebagai sumber pendapatan petani atau masyarakat yang berkecimpung di bidang tanaman hias. Dengan demikian untuk mencapai produksi (bunga, buah, maupun biji) yang tinggi diperlukan teknik pembudidayaan yang tepat dan optimum. Pertumbuhan tanaman yang baik dengan produktivitas tinggi dapat dicapai dengan cara 
memperhatikan syarat-syarat tumbuh dan melakukan pemeliharaan dan perawatan tanaman yang baik. Salah satu pemeliharaan tanaman yang penting adalah pemupukan.

Menurut Sarief (1986), pupuk buatan (anorganik) dapat dikelompokkan menjadi dua, yaitu pupuk tunggal dan pupuk majemuk. Keuntungan pupuk majemuk adalah tidak perlu mencampur pupuk dengan unsur yang berbeda, sehingga lebih efisien, baik dari segi waktu maupun tenaga kerja. Pupuk majemuk adalah jenis pupuk yang mengandung dua atau lebih unsur Nitrogen $(\mathrm{N})$, Phosfor (P), dan Kalium (K) (Adam, Banford, \& Early, 1993). Contoh pupuk majemuk adalah pupuk NPK dan NPK kemasan dengan kombinasi (10:55:10). NPK kemasan (10:55:10) adalah salah satu merek dagang pupuk daun majemuk yang umum tersedia di pasaran.

Pada tanaman hias pemberian pupuk yang berbeda rasio unsur makronya secara bergantian seringkali dilakukan untuk menjaga ketersediaan suplai hara. Hasil penelitian Ginting, Prasetyo, dan Sutater (2001), menunjukkan bahwa pemupukan NPK (25:5:20) sebanyak 3 kali diselingi NPK (10:40:15) sebanyak 1 kali menghasilkan tanaman yang cenderung lebih tinggi produksinya dibandingkan tanaman yang dipupuk dengan NPK (25:5:20) sebanyak 2 kali diselingi NPK (10:40:15) sebanyak 1 kali. Selain itu hasil penelitian Puspitasari (2006), menunjukkan bahwa pemupukan NPK kemasan (32:10:10) sebanyak 3 kali diselingi NPK kemasan (6:30:30) sebanyak 1 kali mampu menghasilkan tanaman anggrek berbunga lebih cepat.

Pupuk anorganik NPK dan NPK kemasan yang tersedia di pasaran memiliki komposisi unsur pupuk yang berbeda satu sama lain, baik unsur makro maupun kelengkapan unsur mikro. Pupuk tersebut berfungsi untuk meningkatkan aktivitas fisiologis tanaman, sehingga dapat mempercepat pertumbuhan vegetatif dan generatif. Untuk memberikan nutrisi bagi tanaman kamboja Jepang dengan kandungan jenis unsur makro dan mikro yang lebih lengkap, serta kadar unsur yang memadai, maka perlu dilakukan pengkombinasian kedua pupuk tersebut. Hasil penelitian Palin (2008), menunjukkan bahwa pemberian kombinasi pupuk berimbang dengan pupuk berkadar $P$ tinggi efektif dalam meningkatkan kualitas pertumbuhan dan pembungaan Adenium.

Berdasarkan latar belakang tersebut, maka perlu dilakukan penelitian mengenai pengaruh pemberian kombinasi pupuk majemuk NPK (25:7:7) dan NPK kemasan (10:55:10) terhadap pertumbuhan vegetatif tanaman kamboja Jepang (Adenium obesum). Dengan demikian penelitian ini bertujuan untuk :

a. Mengetahui pengaruh kombinasi pupuk majemuk NPK (25:7:7) dan NPK kemasan (10:55:10) terhadap pertumbuhan vegetatif tanaman kamboja Jepang.

b. Mendapatkan kombinasi dosis pupuk majemuk NPK (25:7:7) dan NPK kemasan (10:55:10) yang terbaik untuk meningkatkan pertumbuhan vegetatif tanaman kamboja Jepang.

\section{METODOLOGI}

Penelitian dilakukan di Laboratorium Universitas Terbuka, Ciputat-Tangerang untuk persiapan alat dan bahan, serta penimbangan pupuk sesuai dosis yang telah ditentukan. Untuk percobaaan lapang dilakukan di Rumah Naungan, Batan, Setu-Kabupaten Tangerang, mulai bulan Februari sampai dengan Oktober 2008. Alat yang digunakan dalam penelitian ini terdiri dari pot plastik tanaman dengan ukuran diameter $14 \mathrm{~cm}$, sekop, embrat, timbangan analitik, gelas ukur 1000 $\mathrm{mL}$ dan $50 \mathrm{~mL}$, penggaris, thermometer, alat tulis, gunting, kertas label, spidol permanen, spatula, tisu, pengaduk, kantong plastik kecil yang bening, dan mikrometer.

Bahan penelitian yang akan digunakan adalah tanaman kamboja Jepang yang telah berumur sekitar 2,5 bulan, dengan media tanam terdiri dari campuran sekam bakar : pupuk kandang : 
cocopeat : pasir malang : tanah hitam : dolomit dengan perbandingan $3: 1: 1: 1: 1: 0,25$, serta pupuk majemuk NPK (25:7:7) dan pupuk NPK kemasan (10:55:10). Media tanam yang digunakan sebelum dan sesudah perlakuan adalah sama. Untuk menghindari serangan hama dan penyakit akan dilakukan penyemprotan pestisida yang terdiri dari fungisida dan insektisida.

Pot tanaman diatur pada rak bambu yang bernaungan (beratap) dan disusun berdasarkan rancangan percobaan yang telah ditentukan. Percobaan dilakukan dengan Rancangan Acak Lengkap (RAL) dengan pola faktorial $4 \times 4$ dengan 3 kali pengulangan. Faktor I , dosis pupuk NPK (25:7:7) yang terdiri dari 4 taraf : $0 \mathrm{~g} / \mathrm{L} ; 0,5 \mathrm{~g} / \mathrm{L} ; 1 \mathrm{~g} / \mathrm{L} ; 1,5 \mathrm{~g} / \mathrm{L}$. Faktor II, dosis pupuk NPK kemasan (10:55:10), terdiri dari 4 taraf : $0 \mathrm{~g} / \mathrm{L} ; 0,5 \mathrm{~g} / \mathrm{L} ; 1 \mathrm{~g} / \mathrm{L} ; 1,5 \mathrm{~g} / \mathrm{L}$. Dari kedua faktor ini diperoleh 16 kombinasi perlakuan, sehingga jumlah total tanaman yang diamati adalah 48 tanaman.

Data hasil penelitian diuji dengan analisis ragam (ANOVA) untuk mengetahui pengaruh perlakuan terhadap parameter yang diukur, sedangkan untuk mengetahui beda nyata diantara rerata perlakuan digunakan Uji Beda Nyata (LSD) Duncan Multiple Range Test (DMRT) dengan taraf 5 \%. Percobaan dilakukan dengan beberapa tahapan yaitu persiapan, pemeliharaan, perlakuan pemupukan, dan pengamatan vegetatif.

\section{Persiapan}

Tahapan persiapan terdiri dari kegiatan persiapan bibit tanaman, pupuk, fungisida dan insektisida, serta alat yang akan digunakan. Bibit tanaman Adenium dipilih sesuai dengan tingkat keseragaman tanaman (berumur 2,5 bulan) yang selanjutnya dilakukan pelabelan pada bibit tersebut.

\section{Pemeliharaan}

Kegiatan pemeliharaan meliputi penyiraman sekali sehari pada pagi hari antara pukul 07.00 WIB - 09.00 WIB. Pengendalian hama dan penyakit dilakukan dengan cara penyemprotan pestisida, yaitu fungisida dan insektisida 2 minggu sekali secara bergantian. Penyemprotan dilakukan pada pagi hari pukul 07.00 WIB atau sore hari pukul 16.00 WIB. Sanitasi pot dan media tanam dilakukan dengan cara membersihkannya dari gulma.

\section{Perlakuan Pemupukan}

Perlakuan pemupukan terdiri dari kombinasi 2 jenis pupuk yaitu NPK (25:7:7) dan NPK kemasan (10:55:10) yang diberikan secara bergantian seminggu sekali dengan dosis $50 \mathrm{~mL} /$ tanaman. Dengan demikian perlakuan kombinasi dosis pupuk NPK (25:7:7) dengan NPK kemasan (10:55:10) adalah $0 \mathrm{~g} / \operatorname{tanaman} ; 0,025 \mathrm{~g} / \operatorname{tanaman} ; 0,05 \mathrm{~g} / \operatorname{tanaman;}$ dan 0,075 g/tanaman. Pemupukan pertama kali dilakukan 2 minggu setelah penanaman dengan cara menyemprotkan ke seluruh media tanam. Waktu pemupukan adalah pagi hari setiap hari sabtu antara pukul $07.00 \mathrm{WIB}-$ 09.00 WIB.

\section{Pengamatan Vegetatif}

Parameter yang diamati dan diukur adalah tinggi tanaman, panjang daun, lebar daun, jumlah daun, dan diameter batang. Pengukuran dilakukan 4 kali, pertama pada 4 minggu setelah aplikasi (MSA) dan selanjutnya pada interval 4 minggu. Tinggi tanaman (cm), diukur dari pangkal batang di atas permukaan media sampai titik tumbuh dengan menggunakan penggaris atau mistar. Panjang daun $(\mathrm{cm})$ dan lebar daun $(\mathrm{cm})$, pengukuran dilakukan dengan 2 sampel daun dari setiap tanaman yang diambil secara acak. Jumlah daun, daun yang dihitung adalah daun yang telah membuka 
sempurna, tidak cacat, dan tidak terserang hama dan penyakit. Diameter batang $(\mathrm{mm})$, diukur $2 \mathrm{~cm}$ di atas permukaan batang dengan menggunakan alat mikrometer.

\section{HASIL DAN PEMBAHASAN}

Secara umum terjadi peningkatan pertumbuhan tinggi tanaman, panjang dan lebar daun, serta jumlah daun dengan perlakuan kombinasi pupuk majemuk NPK (25:7:7) dan NPK kemasan (10:55:10) dibandingkan dengan kontrol. Pada peubah diameter batang, perlakuan kombinasi pupuk majemuk NPK (25:7:7) (0 g/L) dengan NPK kemasan (10:55:10) (0,5 g/L) dan kombinasi pupuk majemuk NPK (25:7:7) (0,5 g/L) dengan NPK kemasan (10:55:10) (1,5 g/L) hasil pertumbuhannya lebih rendah dibandingkan dengan kontrol. Perlakuan kombinasi pupuk majemuk NPK $(25: 7: 7)(1,5$ $\mathrm{g} / \mathrm{L})$ dengan NPK kemasan (10:55:10) (1,5 g/L) memberikan hasil yang terbaik terhadap semua peubah yang diamati.

Tabel 1. Rata-rata Tinggi Tanaman Tanaman Kamboja Jepang (Adenium obesum) yang Diberi Perlakuan Kombinasi Pupuk Majemuk NPK dan NPK Kemasan

\begin{tabular}{ccrrrr}
\hline \multicolumn{2}{c}{ Perlakuan Kombinasi Pupuk Majemuk } & \multicolumn{4}{c}{ Rata-rata Tinggi Tanaman (cm) } \\
\hline NPK & Kemasan & $4 \mathrm{MSA}$ & $8 \mathrm{MSA}$ & $12 \mathrm{MSA}$ & $16 \mathrm{MSA}$ \\
\hline $0,0 \mathrm{~g} / \mathrm{l}$ & $0,0 \mathrm{~g} / \mathrm{l}$ & 7,16667 & 13,03333 & 19,00000 & 27,80000 \\
& $0,5 \mathrm{~g} / \mathrm{l}$ & 6,83333 & 15,16667 & 18,66667 & 26,26667 \\
& $1,0 \mathrm{~g} / \mathrm{l}$ & 6,76667 & 13,66667 & 19,03333 & 31,00000 \\
& $1,5 \mathrm{~g} / \mathrm{l}$ & 6,73333 & 13,56667 & 19,66667 & 36,33333 \\
$0,5 \mathrm{~g} / \mathrm{l}$ & $0,0 \mathrm{~g} / \mathrm{l}$ & 6,50000 & 16,00000 & 23,66667 & 36,16667 \\
& $0,5 \mathrm{~g} / \mathrm{l}$ & 8,00000 & 17,83333 & 25,70000 & 33,16667 \\
& $1,0 \mathrm{~g} / \mathrm{l}$ & 7,73333 & 15,83333 & 22,33333 & 31,96667 \\
& $1,5 \mathrm{~g} / \mathrm{l}$ & 7,33333 & 14,50000 & 21,83333 & 33,83333 \\
$1,0 \mathrm{~g} / \mathrm{l}$ & $0,0 \mathrm{~g} / \mathrm{l}$ & 8,10000 & 16,66667 & 23,60000 & 34,93333 \\
& $0,5 \mathrm{~g} / \mathrm{l}$ & 8,43333 & 20,16667 & 30,33333 & 44,83333 \\
& $1,0 \mathrm{~g} / \mathrm{l}$ & 6,86667 & 14,50000 & 24,16667 & 43,50000 \\
& $1,5 \mathrm{~g} / \mathrm{l}$ & 8,50000 & 17,00000 & 27,50000 & 49,10000 \\
$1,5 \mathrm{~g} / \mathrm{l}$ & $0,0 \mathrm{~g} / \mathrm{l}$ & 7,83333 & 17,16667 & 24,16667 & 40,90000 \\
& $0,5 \mathrm{~g} / \mathrm{l}$ & 8,13333 & 16,85000 & 26,66667 & 45,93333 \\
& $1,0 \mathrm{~g} / \mathrm{l}$ & 8,73333 & 17,83333 & 26,83333 & 52,00000 \\
& $1,5 \mathrm{~g} / \mathrm{l}$ & 11,06667 & 21,76667 & 30,16667 & 52,16667 \\
\hline
\end{tabular}

Tabel 1 menunjukkan bahwa pemberian kombinasi pupuk majemuk NPK (25:7:7) dan NPK kemasan (10:55:10) dapat meningkatkan tinggi tanaman kamboja Jepang (Adenium obesum). Hasil rata-rata tinggi tanaman yang tertinggi adalah $52,167 \mathrm{~cm}$ oleh pemberian kombinasi NPK $(25: 7: 7)$ $(1,5 \mathrm{~g} / \mathrm{L})$ dan NPK kemasan (10:55:10) (1,5 g/L). Sedang hasil analisis keragaman (ANOVA) yang dilanjutkan dengan uji DMRT ( $\alpha=5 \%$ ) tidak menunjukkan pengaruh yang nyata terhadap tinggi tanaman. Namun pemberian kombinasi pupuk NPK (25:7:7) tanpa NPK kemasan (10:55:10) (0 g/L) memberikan hasil yang nyata dengan nilai signifikansi (p) 0,025 pada pengamatan kedua (8 MSA) dan 0,000 pada pengamatan ke tiga (12 MSA) dan ke empat (16 MSA). Begitu pula pemberian pupuk kombinasi NPK kemasan (10:55:10) tanpa NPK (25:7:7) (0 g/L) memberikan hasil yang nyata dengan nilai signifikansi (p) sebesar 0,010 pada akhir pengamatan.

Pemberian kombinasi pupuk majemuk NPK (25:7:7) dan NPK kemasan (10:55:10) dapat meningkatkan panjang dan lebar daun tanaman kamboja Jepang yang terlihat pada Tabel 2 dan 3. Hasil rata-rata panjang daun tertinggi, yaitu $10,683 \mathrm{~cm}$ dan lebar daun tertinggi, yaitu 4,433 cm dengan pemberian kombinasi pupuk NPK (25:7:7) (1,5 g/L) dan NPK kemasan (10:55:10) (1,5 g/L). 
Berdasarkan hasil ANOVA pemberian kombinasi pupuk NPK kemasan (10:55:10) tanpa NPK (25:7:7) $(0 \mathrm{~g} / \mathrm{L})$ memberikan pengaruh nyata dengan nilai signifikansi ( $p$ ) 0,006 pada akhir pengamatan (16 MSA) terhadap panjang daun tanaman. Sedangkan pemberian kombinasi pupuk majemuk NPK (25:7:7) dan NPK kemasan (10:55:10) berpengaruh nyata terhadap lebar daun tanaman, yaitu pada pengamatan ke dua (8 MSA) dengan nilai $p 0,044$ dan akhir pengamatan (16 MSA) dengan nilai $p$ 0,047 .

Tabel 2. Rata-rata Panjang Daun Tanaman Kamboja Jepang (Adenium obesum) yang Diberi Perlakuan Kombinasi Pupuk Majemuk NPK dan NPK Kemasan

\begin{tabular}{|c|c|c|c|c|c|}
\hline Perlakuan $\mathrm{I}$ & si Pupuk Maje & & Rata-rata Pan & $\operatorname{aun}(\mathrm{cm})$ & \\
\hline NPK & Kemasan & $4 \mathrm{MSA}$ & $8 \mathrm{MSA}$ & $12 \mathrm{MSA}$ & $16 \mathrm{MSA}$ \\
\hline $0,0 \mathrm{~g} / \mathrm{l}$ & $0,0 \mathrm{~g} / \mathrm{l}$ & 4,4667 & 6,8500 & 8,3500 & 8,5667 \\
\hline & $0,5 \mathrm{~g} / \mathrm{l}$ & 4,6000 & 6,3000 & 8,3333 & 8,7667 \\
\hline & $1,0 \mathrm{~g} / \mathrm{l}$ & 4,5500 & 7,5667 & 8,9000 & 9,7500 \\
\hline & $1,5 \mathrm{~g} / \mathrm{l}$ & 5,0333 & 7,7500 & 8,3000 & 9,6500 \\
\hline $0,5 \mathrm{~g} / \mathrm{l}$ & $0,0 \mathrm{~g} / \mathrm{l}$ & 4,7167 & 7,3333 & 7,8500 & 8,5333 \\
\hline & $0,5 \mathrm{~g} / \mathrm{l}$ & 5,2000 & 6,9000 & 7,9833 & 8,6667 \\
\hline & $1,0 \mathrm{~g} / \mathrm{l}$ & 5,5333 & 7,2833 & 9,2167 & 9,7833 \\
\hline & $1,5 \mathrm{~g} / \mathrm{l}$ & 4,6833 & 6,9000 & 8,6667 & 10,5833 \\
\hline $1,0 \mathrm{~g} / \mathrm{l}$ & $0,0 \mathrm{~g} / \mathrm{l}$ & 5,7167 & 6,7833 & 9,1667 & 9,4667 \\
\hline & $0,5 \mathrm{~g} / \mathrm{l}$ & 5,6833 & 7,7500 & 9,3833 & 9,9667 \\
\hline & $1,0 \mathrm{~g} / \mathrm{l}$ & 4,7000 & 7,2333 & 8,5500 & 9,9833 \\
\hline & $1,5 \mathrm{~g} / \mathrm{l}$ & 5,0333 & 7,3667 & 9,3333 & 10,6167 \\
\hline $1,5 \mathrm{~g} / \mathrm{l}$ & $0,0 \mathrm{~g} / \mathrm{l}$ & 5,5833 & 8,2000 & 9,5333 & 9,8167 \\
\hline & $0,5 \mathrm{~g} / \mathrm{l}$ & 4,9333 & 7,4500 & 8,3667 & 9,5500 \\
\hline & $1,0 \mathrm{~g} / \mathrm{l}$ & 5,5167 & 7,4667 & 9,0167 & 10,2000 \\
\hline & $1,5 \mathrm{~g} / \mathrm{l}$ & 6,5167 & 8,8167 & 9,4833 & 10,6833 \\
\hline
\end{tabular}

Tabel 3. Rata-rata Lebar Daun Tanaman Kamboja Jepang (Adenium obesum) yang Diberi Perlakuan Kombinasi Pupuk Majemuk NPK dan NPK Kemasan

\begin{tabular}{|c|c|c|c|c|c|}
\hline \multicolumn{2}{|c|}{ Perlakuan Kombinasi Pupuk Majemuk } & \multicolumn{4}{|c|}{ Rata-rata Lebar Daun (cm) } \\
\hline & & $4 \mathrm{MSA}$ & $8 \mathrm{MSA}$ & $12 \mathrm{MSA}$ & $16 \mathrm{MSA}$ \\
\hline \multirow[t]{4}{*}{$0,0 \mathrm{~g} / \mathrm{l}$} & $0,0 \mathrm{~g} / \mathrm{l}$ & 1,7333 & 2,4167 & 3,0500 & 3,0333 \\
\hline & $0,5 \mathrm{~g} / \mathrm{l}$ & 1,6500 & 2,1167 & 3,2833 & 3,4000 \\
\hline & $1,0 \mathrm{~g} / \mathrm{l}$ & 1,4333 & 2,7000 & 3,3667 & 3,3833 \\
\hline & $1,5 \mathrm{~g} / \mathrm{l}$ & 1,7500 & 2,8500 & 3,6833 & 3,9000 \\
\hline \multirow[t]{4}{*}{$0,5 \mathrm{~g} / \mathrm{l}$} & $0,0 \mathrm{~g} / \mathrm{l}$ & 1,9333 & 3,0000 & 3,4667 & 3,3333 \\
\hline & $0,5 \mathrm{~g} / \mathrm{l}$ & 1,8833 & 2,6500 & 3,2000 & 3,3000 \\
\hline & $1,0 \mathrm{~g} / \mathrm{l}$ & 2,2333 & 2,7000 & 3,8167 & 4,0333 \\
\hline & $1,5 \mathrm{~g} / \mathrm{l}$ & 1,8333 & 2,5833 & 3,3500 & 3,8167 \\
\hline \multirow[t]{4}{*}{$1,0 \mathrm{~g} / \mathrm{l}$} & $0,0 \mathrm{~g} / \mathrm{l}$ & 2,1000 & 2,7667 & 4,0000 & 3,8000 \\
\hline & $0,5 \mathrm{~g} / \mathrm{l}$ & 2,1500 & 3,3667 & 4,1167 & 4,1000 \\
\hline & $1,0 \mathrm{~g} / \mathrm{l}$ & 1,6167 & 2,5167 & 3,1000 & 3,2167 \\
\hline & $1,5 \mathrm{~g} / \mathrm{l}$ & 1,9667 & 2,6000 & 3,4167 & 3,7833 \\
\hline \multirow[t]{4}{*}{$1,5 \mathrm{~g} / \mathrm{l}$} & $0,0 \mathrm{~g} / \mathrm{l}$ & 1,9167 & 2,8167 & 3,6667 & 3,9333 \\
\hline & $0,5 \mathrm{~g} / \mathrm{l}$ & 2,0333 & 3,0667 & 3,6000 & 4,1333 \\
\hline & $1,0 \mathrm{~g} / \mathrm{l}$ & 2,1833 & 3,0833 & 3,7667 & 4,1333 \\
\hline & $1,5 \mathrm{~g} / \mathrm{l}$ & 2,4500 & 3,6000 & 4,1167 & 4,4333 \\
\hline
\end{tabular}


Tabel 4. Rata-rata Jumlah Daun Tanaman Kamboja Jepang (Adenium obesum) yang Diberi Perlakuan Kombinasi Pupuk Majemuk NPK dan NPK Kemasan

\begin{tabular}{|c|c|c|c|c|c|}
\hline \multicolumn{2}{|c|}{ Perlakuan Kombinasi Pupuk Majemuk } & \multicolumn{4}{|c|}{ Rata-rata Jumlah Daun (lbr) } \\
\hline $\mathrm{NPK}$ & Kemasan & $4 \mathrm{MSA}$ & $8 \mathrm{MSA}$ & $12 \mathrm{MSA}$ & $16 \mathrm{MSA}$ \\
\hline \multirow[t]{4}{*}{$0,0 \mathrm{~g} / \mathrm{l}$} & $0,0 \mathrm{~g} / \mathrm{l}$ & 17,33 & 24,67 & 26,33 & 34,67 \\
\hline & $0,5 \mathrm{~g} / \mathrm{l}$ & 17,33 & 23,00 & 29,33 & 40,67 \\
\hline & $1,0 \mathrm{~g} / \mathrm{l}$ & 17,67 & 24,67 & 32,00 & 51,00 \\
\hline & $1,5 \mathrm{~g} / \mathrm{l}$ & 17,00 & 22,00 & 32,00 & 54,00 \\
\hline \multirow[t]{4}{*}{$0,5 \mathrm{~g} / \mathrm{l}$} & $0,0 \mathrm{~g} / \mathrm{l}$ & 18,33 & 28,00 & 35,67 & 58,67 \\
\hline & $0,5 \mathrm{~g} / \mathrm{l}$ & 19,33 & 29,00 & 40,67 & 40,67 \\
\hline & $1,0 \mathrm{~g} / \mathrm{l}$ & 18,00 & 25,00 & 33,00 & 40,33 \\
\hline & $1,5 \mathrm{~g} / \mathrm{l}$ & 18,00 & 26,67 & 36,00 & 28,67 \\
\hline \multirow[t]{4}{*}{$1,0 \mathrm{~g} / \mathrm{l}$} & $0,0 \mathrm{~g} / \mathrm{l}$ & 19,33 & 25,00 & 35,67 & 40,00 \\
\hline & $0,5 \mathrm{~g} / \mathrm{l}$ & 20,67 & 30,33 & 42,00 & 57,00 \\
\hline & $1,0 \mathrm{~g} / \mathrm{l}$ & 18,67 & 26,00 & 37,00 & 58,00 \\
\hline & $1,5 \mathrm{~g} / \mathrm{l}$ & 19,00 & 26,33 & 38,33 & 68,67 \\
\hline \multirow[t]{4}{*}{$1,5 \mathrm{~g} / \mathrm{l}$} & $0,0 \mathrm{~g} / \mathrm{l}$ & 18,00 & 25,00 & 32,00 & 47,00 \\
\hline & $0,5 \mathrm{~g} / \mathrm{l}$ & 18,00 & 30,33 & 34,67 & 40,67 \\
\hline & $1,0 \mathrm{~g} / \mathrm{l}$ & 19,00 & 26,00 & 33,00 & 39,67 \\
\hline & $1,5 \mathrm{~g} / \mathrm{l}$ & 20,33 & 26,33 & 37,67 & 45,00 \\
\hline
\end{tabular}

Tabel 4 menunjukkan bahwa pemberian kombinasi pupuk majemuk NPK (25:7:7) dan NPK kemasan (10:55:10) dapat meningkatkan jumlah daun tanaman kamboja Jepang (A.obesum) mulai dari awal hingga akhir pengamatan. Hasil analisis keragaman menunjukkan pengaruh yang nyata pada akhir pengamatan (16 MSA) dengan nilai signifikansi (p) 0,022.

Berkaitan dengan diameter batang, secara umum perlakuan kombinasi pupuk majemuk NPK (25:7:7) dan NPK kemasan (10:55:10) dapat meningkatkan diameter batang tanaman kamboja jepang (A.obesum), kecuali pada kombinasi pupuk NPK (25:7:7) $(0 \mathrm{~g} / \mathrm{L})$ dengan NPK kemasan $(10: 55: 10)(0,5 \mathrm{~g} / \mathrm{L})$ dan kombinasi pupuk NPK (25:7:7) (0,5 g/L) dengan NPK kemasan (10:55:10) $(1,5 \mathrm{~g} / \mathrm{L})$ hasilnya lebih rendah dibandingkan dengan kontrol (Tabel 5).

Tabel 5. Rata-rata Diameter Batang Tanaman Kamboja Jepang (Adenium obesum) yang Diberi Perlakuan Kombinasi Pupuk Majemuk NPK dan NPK Kemasan

\begin{tabular}{|c|c|c|c|c|c|}
\hline \multicolumn{2}{|c|}{ Perlakuan Kombinasi Pupuk Majemuk } & \multicolumn{4}{|c|}{ Rata-rata Diameter Batang (mm) } \\
\hline NPK & Kemasan & $4 \mathrm{MSA}$ & $8 \mathrm{MSA}$ & $12 \mathrm{MSA}$ & $16 \mathrm{MSA}$ \\
\hline \multirow[t]{4}{*}{$0,0 \mathrm{~g} / \mathrm{l}$} & $0,0 \mathrm{~g} / \mathrm{l}$ & 15,08333 & 21,93033 & 26,85733 & 33,01500 \\
\hline & $0,5 \mathrm{~g} / \mathrm{l}$ & 14,42167 & 18,92000 & 23,88500 & 29,93833 \\
\hline & $1,0 \mathrm{~g} / \mathrm{l}$ & 15,52167 & 20,85767 & 29,83000 & 36,62433 \\
\hline & $1,5 \mathrm{~g} / \mathrm{l}$ & 14,52333 & 20,84667 & 28,45000 & 35,45667 \\
\hline \multirow[t]{4}{*}{$0,5 \mathrm{~g} / \mathrm{l}$} & $0,0 \mathrm{~g} / \mathrm{l}$ & 14,83500 & 21,66500 & 30,89100 & 33,56067 \\
\hline & $0,5 \mathrm{~g} / \mathrm{l}$ & 14,70333 & 20,65167 & 31,42233 & 31,84700 \\
\hline & $1,0 \mathrm{~g} / \mathrm{l}$ & 16,18667 & 21,19333 & 29,93633 & 30,78567 \\
\hline & $1,5 \mathrm{~g} / \mathrm{l}$ & 14,16500 & 19,20833 & 27,38833 & 27,81333 \\
\hline \multirow[t]{4}{*}{$1,0 \mathrm{~g} / \mathrm{l}$} & $0,0 \mathrm{~g} / \mathrm{l}$ & 16,52167 & 22,16500 & 30,46700 & 32,05933 \\
\hline & $0,5 \mathrm{~g} / \mathrm{l}$ & 15,90000 & 24,19333 & 34,71333 & 36,51833 \\
\hline & $1,0 \mathrm{~g} / \mathrm{l}$ & 16,33333 & 22,21167 & 31,20967 & 32,05967 \\
\hline & $1,5 \mathrm{~g} / \mathrm{l}$ & 14,64833 & 22,13333 & 28,87500 & 34,48267 \\
\hline \multirow[t]{4}{*}{$1,5 \mathrm{~g} / \mathrm{l}$} & $0,0 \mathrm{~g} / \mathrm{l}$ & 15,54667 & 20,98167 & 29,19433 & 35,03200 \\
\hline & $0,5 \mathrm{~g} / \mathrm{l}$ & 15,81667 & 21,27667 & 28,55600 & 34,18467 \\
\hline & $1,0 \mathrm{~g} / \mathrm{l}$ & 15,87667 & 23,16500 & 28,23900 & 30,57333 \\
\hline & $1,5 \mathrm{~g} / \mathrm{l}$ & 17,87667 & 24,89833 & 35,45633 & 36,83633 \\
\hline
\end{tabular}


Hasil rata-rata diameter batang tertinggi, yaitu $36,836 \mathrm{~mm}$ oleh perlakuan kombinasi pupuk majemuk NPK (25:7:7) (1,5 g/L) dan NPK kemasan (10:55:10) (1,5 g/L). Berdasarkan hasil analisis keragaman menunjukkan pengaruh yang nyata pemberian kombinasi pupuk NPK (25:7:7) dan NPK kemasan (10:55:10) terhadap pertumbuhan diameter batang yaitu pada pengamatan ke tiga (12 MSA) dengan nilai signifikansi (p) 0,023.

Dari hasil penelitian didapatkan bahwa perlakuan kombinasi pupuk majemuk NPK (25:7:7) dan NPK kemasan (10:55:10) dapat meningkatkan pertumbuhan tinggi tanaman. Kombinasi yang memberikan pengaruh paling tinggi terhadap peningkatan pertumbuhan tinggi tanaman kamboja Jepang (Adenium obesum) yaitu kombinasi pupuk majemuk NPK (25:7:7) (1,5 g/L) dengan NPK kemasan (10:55:10) (1,5 g/L). Hal ini menunjukkan bahwa semakin tinggi konsentrasi yang diberikan, maka semakin banyak unsur hara yang diperoleh tanaman, sehingga akan dihasilkan tinggi tanaman yang semakin tinggi pula (Mardjuki, 1994). Pernyataan ini juga didukung oleh pernyataan Widiastoety dan Santi (1997) bahwa kuantitas dan kualitas pupuk dapat mengatur keseimbangan pertumbuhan vegetatif (akar, batang, dan daun) dan generatif (bunga) tanaman.

Kombinasi pupuk majemuk NPK (25:7:7) (1,5 g/L) dengan NPK kemasan (10:55:10) (1,5 g/L) tidak hanya meningkatkan pertumbuhan tinggi tanaman saja, melainkan juga pada panjang dan lebar daun, jumlah daun, serta diameter batang, kombinasi tersebut memberikan hasil yang tertinggi pada tanaman kamboja Jepang. Hal ini kemungkinan disebabkan adanya hubungan antara tinggi tanaman dengan peubah-peubah lainnya yang diamati dalam penelitian ini, yang semuanya berhubungan dengan fase pertumbuhan vegetatif. Panjang dan lebar daun, serta jumlah daun yang tinggi memungkinkan hasil fotosintetis yang besar, sehingga tanaman memiliki nutrisi yang cukup untuk pertumbuhannya dalam hal ini pertumbuhan vegetatif.

Menurut Setyamidjaja (1986) bahwa pada fase vegetatif perlu diberikan pupuk berkadar $\mathrm{N}$ tinggi karena unsur tersebut merupakan bahan pokok untuk menyusun protein yang sangat dibutuhkan dalam pembelahan sel, dan unsur mikro yang lebih lengkap. Unsur N yang berkadar tinggi dalam penelitian ini dipenuhi oleh pemberian pupuk NPK (25:7:7). Sedang adanya unsur hara Ca, S, Fe, dan Mo pada pupuk NPK kemasan (10:55:10) sebagai unsur mikronya, secara tidak langsung memacu pertumbuhan vegetatif tanaman kamboja Jepang. Menurut Hew dan Young (1997), unsur Ca adalah unsur hara yang berperan penting dalam pertumbuhan sel dan kelancaran fotosintesis. Kekurangan unsur S, Fe, dan Mo akan menyebabkan pertumbuhan tanaman terhambat.

Haryadi (1996) menyatakan bahwa fase reproduksi pada tanaman memerlukan suplai karbohidrat dan pada fase ini tanaman tersebut menyimpan sebagian besar karbohidrat yang dibentuknya. Pada penyelingan pupuk dengan kandungan $\mathrm{N}$ yang tinggi diimbangi dengan pupuk yang mengandung $\mathrm{P}$ dan $\mathrm{K}$ yang tinggi pula diduga mampu mengatasi cadangan karbohidrat yang hilang. Wilfret (1980) mengemukakan bahwa kandungan $P$ yang tinggi, dalam hal ini yang terdapat dalam pupuk NPK kemasan (10:55:10) dapat mendorong pendewasaan tanaman yang selanjutnya membantu proses pembungaan. Hal ini didukung oleh pernyataan Parker (2004) bahwa Phosfor (P) merupakan unsur makro esensial untuk pertumbuhan dan reproduksi tanaman.

\section{KESIMPULAN DAN SARAN}

Dari hasil penelitian dapat disimpulkan bahwa pemberian kombinasi pupuk majemuk NPK (25:7:7) dan NPK kemasan (10:55:10) dapat meningkatkan pertumbuhan vegetatif tanaman kamboja Jepang dengan kombinasi terbaik pupuk majemuk NPK (25:7:7) (1,5 g/L) dan NPK kemasan $(10: 55: 10)(1,5 \mathrm{~g} / \mathrm{L})$. 
Untuk penelitian lebih lanjut perlu diketahui pula pemberian kombinasi pupuk majemuk terhadap pertumbuhan generatif tanaman kamboja Jepang sehingga dapat dicapai pertumbuhan optimum yang diinginkan. Selain itu menarik pula diketahui pengaruh perlakuan pupuk organik atau zat pengatur tumbuh terhadap pertumbuhan tanaman kamboja Jepang.

\section{REFERENSI}

Adam, C.R., Banford, K.M. \& Early, M.P. (1993). Principle of Hoticultura. (2nded). London: Butterwoth, Heinemann. Oxford. 204 p.

Ginting, B. , Prasetio, W., \& Sutater, T. (2001). Pengaruh cara pemberian, air, media, dan pemupukan terhadap pertumbuhan Anggrek Dendrobium. J.Hort. 11 (1), 22-29.

Haryadi, S. S. (1996). Pengantar agronomi. Jakarta : PT Gramedia. 197 hal.

Hew, C. S.\& Young, J. W. H. (1997). The Physiology of tropical orchids in relation to the industry. World Scientific.

Mardjuki, A. (1994). Pertanian dan masalahnya. (2nded). Yogyakarta: Penerbit Andi Offset.

Palin, M. (2008). Uji efektifitas kombinasi pupuk berimbang dengan pupuk berkadar $P$ tinggi untuk memacu pertumbuhan dan pembungaan Adenium. Bogor: Fakultas Pertanian, IPB.

Parker, R. (2004). Introduction to Plant Science. United States. America.

Puspitasari, D.T. (2006). Pengaruh perlakuan pemupukan terhadap pertumbuhan vegetatif dan generatif tanaman Anggrek Dendrobium. Bogor: Fakultas Pertanian, IPB.

Sarief, E.S (1986). Kesuburan dan pemupukan tanah pertanian. Bandung: Pustaka Buana.

Setyamidjaja, D. (1986). Pupuk dan pemupukan. (1sted). Jakarta: CV Simplex.

Untung, O. (2006). Adenium. Trubus info kit. Jakarta: Trubus Swadaya.

Widiastoety, D. \& Santi, A. (1997). Pembibitan dan budidaya anggrek. Jakarta: Balai Penelitian Tanaman Hias.

Wilfret. (1980). Gladiolus. In R.E. Larson (Ed). Introduction to floriculture. New York: Acad. Press. 